\title{
Alcohol Dehydrogenase Diversified Pattern of Indian Major and Exotic Carps
}

\author{
Amita Saxena*, Ningthoukhongjam Soranganba \\ Department of Fishery Resource Management, College of Fisheries, G. B. Pant University of Agriculture and Technology, India
}

Copyright (C) 2016 by authors, all rights reserved. Authors agree that this article remains permanently open access under the terms of the Creative Commons Attribution License 4.0 International License

\begin{abstract}
Isozyme pattern were studied in six teleost species of Catla (Catla catla), Rohu (Labeo rohita), Mrigal (Cirrhinus mrigala), Common carp (Cyprinus carpio), Grass carp (Ctenopharyngodon idella) and Silver carp (Hypophthalmichthyes molitrix) from gill, muscle, heart and kidney tissues. Alcohol dehydrogenase (ADH) were separated in native-PAGE of 7.5\% gradient. ADH-1 and $\mathrm{ADH}-2$ loci were observed and comparison of Rm value of the polypeptide show different diversified enzyme activities which were sync with their feeding metabolic, habitat and environmental factors. The overall observation was found to be tissue specific.
\end{abstract}

Keywords ADH, Isozymes, Indian Major Carps, Exotic Carps, Native-PAGE

\section{Introduction}

Alcohol dehydrogenase (ADH; alcohol: NAD+ oxidoreductase, EC 1.1.1.1) is the enzyme that catalyzes the interconversion of alcohols with the corresponding aldehydes and ketones and are widely distributed in micro organisms, plants and animals [25]. Though the presence of $\mathrm{ADH}$ has been demonstrated, [9] there is relatively little information in fish and few studies can be found concerning fish $\mathrm{ADH}$ in the literature [14,18,19,20,24,25]. Genetic modification occurs inadvertently in a cultured population. Population study can aid in the management of fish populations [28] and a large amount of genetic differentiation can occur within a small geographic area [29]. Since there is no competition for food and fear for predators, a farmed fish population experiences different kinds of selection regimes unprecedented in natural waters. It becomes domesticated after some generation of breeding and culture, which bring about changes in morphology, physiology and/or behaviour of the domesticated fish [17]. The composite or multi-species culture technologies so far developed are based on species manipulation and application of certain management practices.
Molecular genetic markers have been applied to three fisheries areas in particular-stock structure analysis, aquaculture and taxonomy/systematic [27] with varying degree of success [3]. All these techniques have their advantages and disadvantages in analysis of genetic variability in fishes [26, 8]. Some advantages of protein electrophoretic methods include their speed and simplicity; disadvantages include a requirement for fresh or frozen tissue, relatively low level of variation and uncertainty over whether the variability recorded is natural or subject to selective pressure.

The isozyme electrophoretic technique is ideally suited to population studies as it is fairly rapid procedure to perform on a large scale, and a large number on unlinked loci that are dispersed throughout the genome can be screened simultaneously [16]. Moreover, it is relatively inexpensive and requires little in the way of specialized equipment. Isozymes are multi form of an enzyme that often appears in different molecular forms in a species. They are forms to meet the varying metabolic conditions of an organism. Any detectable changes in isozyme electrophoretic pattern between different types or individual reflect certain genetic variation and are thus regarded as good genetic markers [15].

Taking advantage of mutually compatible and complimentary food habits of Indian major carps and exotic carps, the present day intensive and extensive polyculture culture popularly known as composite carp culture has been developed and has demonstrated a gradual increase in the fish production from 3-4t/ha/year to 10-15t/ha/year.[4,5,6,27]. However, in the absence of proper breeding plans, this has led to a gradual decline in the genetic quality of the seed. Consequently the negative effect on inbreeding started appearing with the characteristic poor survival and slow growth, besides disease susceptibility of the hatchery produced seed [11].

Considering the above aspects, the present study for analysis of tissue specific ADH pattern on six species of Catla (Catla catla), Rohu (Labeo rohita), Mrigal (Cirrhinus mrigala), Common carp (Cyprinus carpio), Grass carp (Ctenopharyngodon idella) and Silver carp (Hypophthalmichthyes molitrix) has been carried out. 


\section{Materials and Methods}

\section{Source of fish}

Species of Catla (Catla catla), Rohu (Labeo rohita), Mrigal (Cirrhinus mrigala), Common carp (Cyprinus carpio), Grass carp (Ctenopharyngodon idella) and Silver carp (Hypophthalmichthyes molitrix) were collected using seine net of mesh size $3 \mathrm{~cm}$ from the instructional fish farm, College of Fisheries, Pantnagar.

\section{Collection of fish tissue}

Live specimen were taken to laboratory and dissected under aseptic condition for the collection of the target tissue. Tissues were collected from four organs viz. muscles (just below the dorsal fin), gill, heart and kidney. And collection tissue were immediately frozen at $-1^{\circ} \mathrm{C}$ and transported to the College of Basic Science and Humanities, Pantnagar and stored at $-20^{\circ} \mathrm{C}$ till further use. Frozen tissue were thawed at $4^{\circ} \mathrm{C}$ and $1 \mathrm{~g}$ of different tissue were homogenized using ground glass homogenizer under chilled conditions in 0.01 $\mathrm{M}$ Tris- $\mathrm{HCl}$ buffer of $\mathrm{pH} 6.8$ having $1 \mathrm{mM}$ EDTA. Then the homogenized samples were centrifuged at 10,000 rpm for 30 mins at $4^{\circ} \mathrm{C}$.

\section{Reagents used}

30\% Acrylamide:Bisacrylamide solution (37.5:1), 4X Separating buffer (Tris Hydroxymethylamine methane at $\mathrm{pH}$ 8.8), 4X Stacking buffer (Tris- $\mathrm{HCl}$ at $\mathrm{pH}$ 6.8), $10 \%$ Ammonium persulphate, TEMED (N,N,N',N', tetramethly ethylene diamine), $\mathrm{H}_{2} \mathrm{O}$-saturated n-butanol, electrophoresis buffer $(0.025 \mathrm{M}$ Tris with $0.192 \mathrm{M}$ glycine at $\mathrm{pH} 8.3), 2 \mathrm{X}$ sample buffer (bromophenol blue $0.5 \%$ and glycerol $40 \%$ )

Table 1. Recipe for gel preparation for nondissociating discontinuos buffer system

\begin{tabular}{|c|c|c|}
\hline Stock Solution & $\begin{array}{c}\text { Stacking gel } \\
4 \%\end{array}$ & $\begin{array}{c}\text { Separating gel } \\
\text { mixture } 7.5 \%\end{array}$ \\
\hline $\begin{array}{c}30 \% \text { Acrylamide: } \\
\text { Bisacrylamide solution }\end{array}$ & $2.6 \mathrm{ml}$ & $15 \mathrm{ml}$ \\
\hline 4X Separating buffer & - & $15 \mathrm{ml}$ \\
\hline 4X Stacking buffer & $5.0 \mathrm{ml}$ & - \\
\hline Distilled water & $12.2 \mathrm{ml} \mathrm{ml}$ & $300 \mu \mathrm{l}$ \\
\hline $10 \%$ Ammonium persulphate & $100 \mu \mathrm{l}$ & $20 \mu \mathrm{l}$ \\
\hline TEMED & $10 \mu \mathrm{l}$ & \\
\hline
\end{tabular}

\section{Procedure}

Approximately $60 \mathrm{ml}$ of the separating gel of $7.5 \%$ concentration were prepared; $30 \mathrm{ml}$ per plate as given in Table 1 and pour at a level of $5 \mathrm{~cm}$ below the notch. Water saturated n-butanol of $0.3 \mathrm{ml} / \mathrm{gel}$ was used to get smooth surface of the separating gel and washed away using distilled water after polymerization of the gel.
After pouring the stacking gel, comb were fixed and left for polymerization. Bottom spacers were removed after polymerization and the unit was attached to the electrophoresis apparatus after filling with electrode buffer at lower and upper tank. $10 \mu \mathrm{l}$ of sample containing were dissolved in sample buffer and applied in each slot. Electrophoresis was performed under chilled condition of $4^{0} \mathrm{C}$ at 80 volts constant voltage for 20 minutes and then 110 volts till indicator dye approached the gel bottom. After which spacer was removed and gel was stained at specific staining dye.

\section{Specific Enzyme staining}

The visualization of $\mathrm{ADH}$ isozyme on gel was carried out with certain modifications [27].

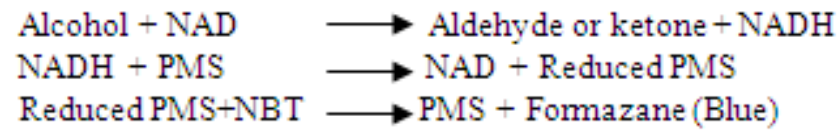

Table 2. Recipe for ADH staining

\begin{tabular}{|c|c|}
\hline 0.2 M Tris/HCL pH 8.0 & $240 \mathrm{ml}$ \\
\hline NAD & $96 \mathrm{mg}$ \\
\hline Ethyl alcohol $(95 \%)$ & $8 \mathrm{ml}$ \\
\hline PMS & $16 \mathrm{mg}$ \\
\hline NBT & $64 \mathrm{mg}$ \\
\hline Distilled water & $160 \mathrm{ml}$ \\
\hline
\end{tabular}

\section{Fixing of Gel}

Once the reaction for staining of a given enzyme system had been carried out on gel, the stain developed somewhere between the following two extremes:

a) The staining was very slow and the gels were left overnight before fixing.

b) Standard fixative contained $40 \%$ methanol and $10 \%$ acetic acid in distilled water.

\section{Photography}

Gels needed to be photographed so that they could be interpreted properly. Sometimes the bands spread out and the gel becomes uninterruptible after overnight staining. Thus a series of photographs were necessary. Photos were taken using gel documentation system. Proper labeling was done regarding fish number and name of enzyme photographed.

\section{Analysis of gels}

The band were recorded and the data obtained were expressed as Relative mobility ( $\mathrm{Rm})$ given as migration distance of polypeptides upon migration distance of tracking dye.

\section{Results}


Table 3. Bands observed in four tissues of Indian Major and Exotic carps

\begin{tabular}{|c|c|c|c|c|}
\hline Fish Species & Lane & Tissue & $\mathrm{ADH}-2$ & $\mathrm{ADH}-1$ \\
\hline \multirow{4}{*}{ Labeo rohita } & G1 & Gill & - & - \\
\hline & M1 & Muscle & + & + \\
\hline & H1 & Heart & + & - \\
\hline & K1 & Kidney & + & - \\
\hline \multirow{4}{*}{ Catla catla } & G2 & Gill & - & - \\
\hline & M2 & Muscle & + & + \\
\hline & H2 & Heart & + & + \\
\hline & K2 & Kidney & + & - \\
\hline \multirow{4}{*}{ Cirrhinus mrigala } & G3 & Gill & - & - \\
\hline & M3 & Muscle & + & + \\
\hline & H3 & Heart & - & + \\
\hline & $\mathrm{K3}$ & Kidney & + & + \\
\hline \multirow{4}{*}{$\begin{array}{l}\text { Hypophthalmichthys } \\
\text { molitrix }\end{array}$} & G4 & Gill & - & - \\
\hline & M4 & Muscle & + & + \\
\hline & H4 & Heart & - & + \\
\hline & K4 & Kidney & + & - \\
\hline \multirow{4}{*}{ Ctenopharyngogon idella } & G5 & Gill & + & + \\
\hline & M5 & Muscle & + & - \\
\hline & H5 & Heart & + & + \\
\hline & K5 & Kidney & + & - \\
\hline \multirow{4}{*}{ Cyprinus carpio } & G6 & Gill & - & - \\
\hline & M6 & Muscle & + & - \\
\hline & H6 & Heart & + & - \\
\hline & K6 & Kidney & + & - \\
\hline
\end{tabular}

(Here the sign "+" indicate the presence of band and "_. indicates the absence of band)
Table 4. Enzyme and its observation in six composite species of Indian major and Exotic carp

\begin{tabular}{|c|c|c|c|c|}
\hline Enzyme & E.C. No & Abbreviation & $\begin{array}{c}\text { No. of loci } \\
\text { observed }\end{array}$ & Tissues \\
\hline $\begin{array}{c}\text { Alcohol } \\
\text { dehydrogenase }\end{array}$ & 1.1 .1 .1 & ADH & 2 & Gill \\
& & & 2 & Muscle \\
& & 2 & Heart \\
& & & Kidney \\
\hline
\end{tabular}

(a) Gill

Only C. idella shows the enzymatic activity with $\mathrm{Rm}$ values of 0.33 and 0.38 respectively (Fig 1a). The absence of bands observed in other species may be due to non-expression of this particular enzyme.

(b) Muscle

There is fair expression in muscle having two bands each except in C. idella and C. carpio (Fig 1b). C. catla - C. mrigala has similar ADH-1 bands while L. rohita - C. catla and C. mrigala - H. molitrix have similar ADH-2 banding pattern.

(c) Heart

L. rohita and C. catla shows two bands each while the remaining species show only one band each (Fig1c). C. catla - C. mrigala shows similar ADH-1 bands while L. rohita Common and C. catla - C. idella shows similar ADH-2 banding pattern respectively.

(d) Kidney

All the species except $C$. mrigala shows both ADH-1 and ADH-2 banding pattern (Fig 1d). L. rohita - C. catla and C. mrigala - H. molitrix - C. idella showing similar banding pattern respectively. 


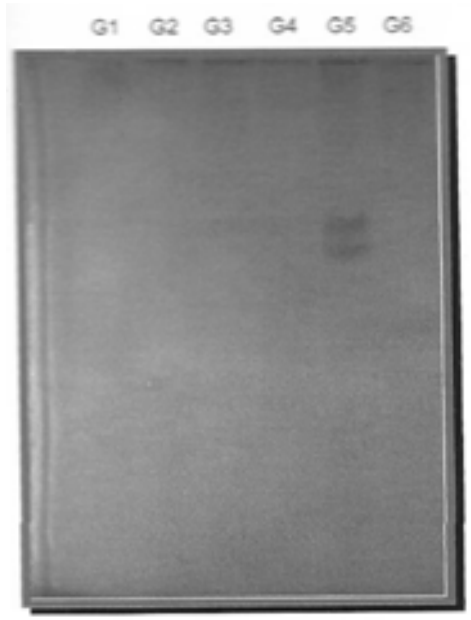

(a)

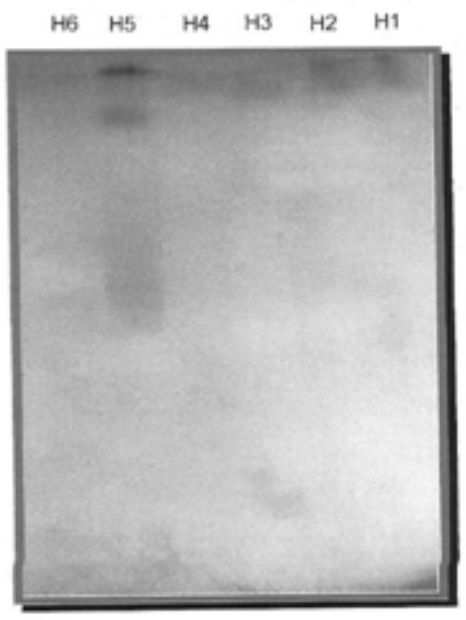

(c)

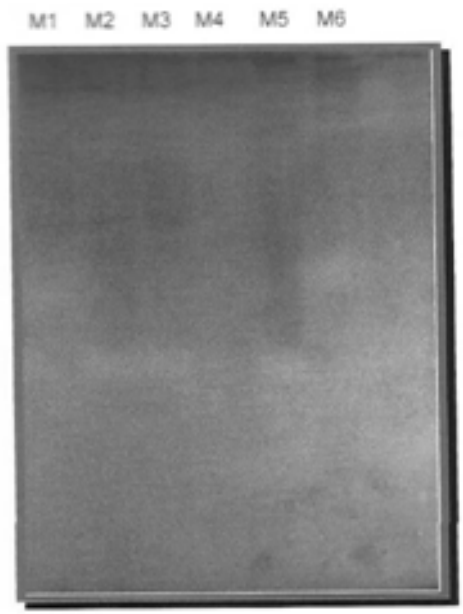

(b)

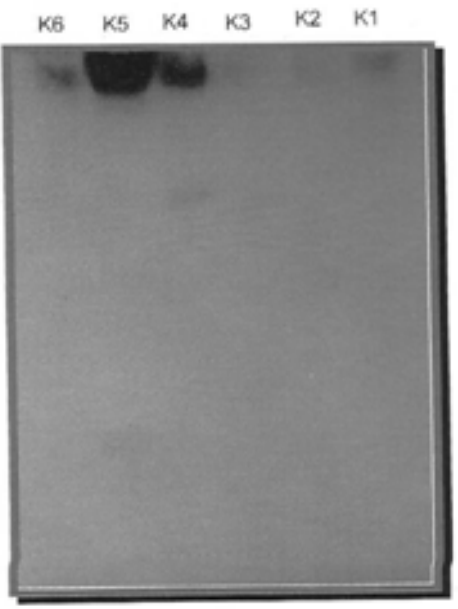

(d)

Figure 1. Alcohol dehydrogenase isozyme pattern on $7.5 \%$ gradient polyacrylamide gel

Staining of specific enzymes is preferred over general proteins for diversity analysis of fish population due to several reasons. First, the often complex patterns resulting from large number of bands revealed any non-specific staining [25] can make the interpretation of gel extremely difficult. Secondly, important information such as inheritance data from other species, data concerning the subunit structures about the influence of environment variables and different physiological status on the expression of the characters is almost lacking for general proteins [26]. Third, the action of any number of non-genetic factors that can affect protein banding patterns is difficult to detect and document because of complexity and large unknown genetic and physiological bases of general protein pattern [26]. However, these lacunae can be overcome by specific enzyme staining. In fact, $\mathrm{ADH}$ is probably the most important dehydrogenase involved in metabolism of exogenous and endogenous alcohol in liver $[12,10]$ and was distributed in most organs in fish [27]. It has been pointed out that ADH activity parallels dietary habits in fishes [13]. Thus the difference in the $\mathrm{Rm}$ values and the banding pattern observed in the present study can be due to the different ecological niche occupied by these cyprinids.

Expression of ADH activity in Grass carp gill may be due to their feeding habit as they are always on the move, the amount of water and suspended solids passing through the gill are huge and more alcohol are require in order to clean the detritus trapped in between the gill lamellae which would further require more $\mathrm{ADH}$ to mobilize it.

The presence of one band each of low mobility in muscle tissue of C. idella and C. carpio may be due to the difference in anaerobic energy yielding mechanism in this species against the normal mode of glycolysis initiation given by $\mathrm{NAD}+$ which is derived from pyruvate via acetaldehyde under anaerobic conditions.

On the contrary, heart tissue in C. idella shows the distinctively highest mobility.

Kidney tissue only in C. mrigal shows two bands while remaining species shows the presence of only $\mathrm{ADH}-2$ as in other vertebrate kidney where there is little ADH activity [26] which can be due to relative small kidney as small fish liver may play a more important role in alcohol oxidation than that 
of a large fish body [5]. Krebs and Perkins [12] found that in mammals, with the exception of cattle, ADH activity was generally lower in carnivores than in herbivores and omnivores. Since ADH activity was found in other organs and tissues, it is necessary to clarify the physiological and enzymological roles other than the alcohol oxidation in each organ and tissue [5].

ADH being a dimer exhibit two band each in all the tissues even though the intensity of the banding pattern differ from one to another and are tissue specific. In case of gill none other than C. idella express this enzyme. ADH-1 is expressed only in the kidney tissue of $\mathrm{C}$. mrigal. ADH-2 expressed more prominently in all the tissue than ADH-1.

Thus, it is concluded that the species investigated being of the same family possess very close relationship with respect to the isozyme pattern and open up further research in the field of population genetics, cytogenetics, molecular genetics, recombinant DNA technology, aquaculture genetics etc. And it is suggested to investigate more number of enzymes and their polymorphic loci along with DNA based markers with large number of sample size for better understanding and sustainable utilization of the genetic diversity of this economically important composite fish species.

\section{Acknowledgements}

One of the authors Mr Ningthoukhongjam Soranganba is highly thankful to ICAR for providing financial help as JRF.

\section{REFERENCES}

[1] Allendorf, F. W.; Mitchell, N.;Ryman, N. and Stahl, N (1997). Isozyme loci in brown trout (Salmo trutta L.): detection and interpretation from population data. Hereditas 86: 179-190

[2] Allendorff,. W. and Utter, F. M. (1977). Population genetics of fish. - Fish Physiol. 8

[3] Carvalho, G.R. and Houser, L. (1994). Molecular genetics and stock concept in fishes. Rev. Fish. Biol. Fish. 4:326-350

[4] Chaudhuri, H.R.D.; Chakraboty, R.D.; Rao, N.G.S.; K.; Janakiram, D.K. Chatterjee and S. Jena. (1974). Record production with intensive culture of Indian and exotic carps. Curr. Sci. 43(10):303-304

[5] Chaudhuri, H.R.D.; Chakraboty, R.D.; Sen, P.R.; Rao, N.G.S.; $\mathrm{K}$ and S. Jena. (1975). A new high in composite fish culture in freshwater ponds. Aquaculture, 6:343-355

[6] Chaudhuri, H.R.D.; Rao, N.G.S.; Saha, G.N.; Rout, M. And Kanauji, D.R. (1978). Record fish production through intensive fish culture in a farmer's pond. J. Inland Fish. Soc. India. 10:19-27
[7] Danielsson, O; Eklund, O. and Joernvall, O: The major piscine liver alcohol dehydrogenase has class-mixed properties in relation to mammalian alcohol dehydrogenase of classes I and III. Biochemistry, 31, 3751-3759 (1992).

[8] Ferguson, M.M. and Danzmann, R.G. (1998). Role of genetic marker in fisheries and aquaculture: Useful tools or stamps collection. Can. J. Fish. Aquat. Sci. 55:1553-1563

[9] G. E. Nilsson: J. Comp. Physiol., 158B, 479-485 (1988).

[10] Hodgson, E. and P.E. Levi. (1994). Metabolism of toxicants: Phase I reactions. In: Introduction to biochemical toxicology. 2nd ed. E. Hodgson and P.E. Levi, eds.

[11] Ibrahim, K.H.; Kotwal, S.D. and Gupta, S.D. (1988). Embryonic and larval development among Catla catla and Hypophthalmichthys molitrix hybrid. J. Inland Fish. Soc. India. 12 (2):69-73

[12] Krebs, H.A. and J.R. Perkins. (1970). The physiological role of liver alcohol dehydrogenase. Biochem. J. 118: 635-

[13] Nagayama, F. and T. Yoshikiyo. (1975). Properties of fish liver alcohol dehydrogenase. J. Tokyo Univ. Fish. 62: 39-44 (In Japanese with English abstract).

[14] O. Danielsson, H. Eklund, and H. Joernvall: The major piscine liver alcohol dehydrogenase has class-mixed properties in relation to mammalian alcohol dehydrogenase of classes I and III. Bio chemistry, 31, 3751-3759 (1992)

[15] Pandhi, B.K. \& Mandal, R.K. (2000). Applied fish genetics. Fishing Chimes publication. 59-67

[16] Park, L.K. and Moran, P. (1994). Development in molecular genetic techniques in fisheries. Rev. Fish. Biol. Fish. $4: 272-299$

[17] Robinson, B.W. and Doyle, R.W. (1990). Phenotypic correlation among behaviour and growth variables in Tilapia: Implication of Domestication Selection.

Aquaculture.85:177-186

[18] Saxena A. and Soranganba N (2013). Diversified isozyme pattern of ADH in different tissues of six teleosts. Aquaculture Europe. Norway Aug.09-12 (Abstract)

[19] Saxena A. and Soranganba N (2014). Protien diversity in various tissue of the body of carps. Biol. And Chem. Res. Vol. $1(2): 108-122$

[20] Saxena A.; Soranganba N; Mishra D.P.; Gaur A.K. (2012). Superoxidase banding in Indian and exotic carps. J. Trends of Fisheries Res. 1(1): 25-31

[21] Shaklee, J.B. and Kenan, C.P. (1986). A practical laboratory guide to technique and methodology of electrophoresis and its application in fish fillet identification. Report 177, CSIRP, Australia, Marine laboratories. 519

[22] Shaklee, J.B.; Phelps, S.R. and Salini, J. (1990). Analysis of fish stock structure and mixed stock fisheries by electrophoretic characterisation of allelic isozyme. In: Whitmmore, D.H. ed. Electrophoretic and isoelectric focussing techniques in fisheries management. CRC press. Boca raton, Florida. 173-196T

[23] Shaw, C.R. and Prasad, R. (1970). A compilation of recipes for starch gel electrophoresis. Biochemical Genetics. 4:297-320 
[24] Soranganba N. and Saxena A. (2012). Esterase diversity in Indian and Exotic carps. J. Trends of Fisheries Res. 1(1): $07-13$

[25] Takeshi N., Moritsugu H, Norihisa K, Yasuhiro T., and Fumio N. (1997) Short Paper Organ Distribution of Alcohol Dehydrogenase Activity in Several Fish. Fisheries Science 63(2), 323-324

[26] Takeshi, N.,; Moritsugu H,; Norihisa,;Yasuhiro T. and Fumio N. (1996). Purification and Characterization of Alcohol Dehydrogenase from Liver of Skipjack Katsuwonus pelamis. Fish Sci. 62(2), 272-277.

[27] Tripathi, S.D.; Aravindakshan, P.K.; Ayyappan, S; Jana, J.K.; Muduli, H.K.; Chandra, S and Pani, K.C. (1997). New dimension in intensive fish culture in India. Publisher B.V., Amsterdam-The Netherlands.

[28] Urich, K. (1994). The freshwater fishes of Taiwan. Taiwan prov. Educ. Dept. Press, Taipei, 197(Translated).

[29] W. P. Fong: Isolation and characterization of grass carp (Ctenopharyngodon idellus) liver alcohol dehydrogenase. Comp. Biochem. Physiol., 98B, 297-302 (1991).

[30] Ward, R. D. (2000). Genetics in fisheries management. Hydrobiologia. 420:191-201

[31] Ward, R.D. and Grewe, P.M. (1994). Appraisal of molecular genetics techniques in fisheries. Rev. Fish. Biol. Fish. 4:300-325. 